УДК $78.01 / 78.05+781.7$

\author{
Лу Цзе
}

\title{
КАТЕГОРІЯ «КОНЦЕПТУ» В ПАРАДИГМІ ЕВРОПЕЙСЬКОЇ ТА КИТАЙСЬКОЇ МУЗИЧНОЇ КУЛЬТУРИ
}

\begin{abstract}
У статті зіставляються провідні концепти європейської та китайської традиції, що проектуються на художньо-естетичний світогляд китайських музикантів і композиторів. Категорія «концепту» в ії проекції на музичне начало видається в цьому ракурсі цілком доречною, оскільки дозволяє вловити глибинний рівень змісту, який, хоч і присвоює собі в значній мірі специфіку європейського художнього мислення, все ж у своєму первинному значенні завжди спирається на національне світовідчуття у його духовно-філософських вимірах, у його особливому способі поєднання музичної інтонації та слова.
\end{abstract}

Ключові слова: концепт, концептосфера, національна музична культура, домінанта концепту.

В останній час гуманістична наука, і в тому числі - музикознавство різних країн і континентів виявляє дивовижну збіжність інтересу до певних фундаментальних категорій буття і розвитку різного типу мистецьких явищ і феноменів, що отримують нові тлумачення і розглядаються під доволі незвичним кутом зору. Очевидно, такий виток еволюції гуманістичної думки був закономірним: процеси глобалізації не могли залишити без уваги засади функціонування музичної культури, і в актуальному взаємопереплетенні і взаємовпливах різних цивілізаційних зрізів у інтонаційній візії світу вони природно концентруються на деяких основоположних поняттях. Одне з них - поняття концепту, шо останнім часом починає прикладатись не лише до етноментальної, соціологічної та історичної сфер наукового пізнання, але й до мистецтва, в тому числі й до музики.

Але застосовуючи категорію «концепту» в дослідженні музичних артефактів чи ширше - явищ музичної культури, не можемо випускати з уваги особливості його застосування в площині розмаїтих історико-цивілізаційних зрізів. Під тим оглядом видається цікавим зіставити провідні концепти європейської та китайської традиції i спроектувати їх на художньо-естетичний світогляд китайських музикантів і композиторів. Особливо цікаво й багатогранно відбуваються зміни і самого цього світогляду і його провідних концептів у XX ст. коли китайські композитори вельми сумлінно переймали великий досвід європейських мистецьких центрів, опановували типово єв-

(C) Лу Цзе, 2015 
ропейські інструменти, жанри, способи впровадження академічної музики в соціум, в тому числі, наприклад, за короткий час популяризували у своїй дидактичній та концертній практиці фортепіано, скрипку - і почали активно творити симфонічні жанри, в 20-х роках ХХ ст. заснували перші консерваторії європейського типу, що стрімко заповнили всю мапу країни - і китайські виконавці дуже впевнено опанували найширші пласти європейського репертуару тощо.

Та попри всі інновації і потужний процес «європеїзації», що суттєво змінив напрямки розвитку далекосхідного мистецтва, в тому числі й Китаю, все ж ментальна основа своєрідно і художньо переконливо інтегрується в тематику і засоби виразності, якими користуються китайські митці. Категорія «концепту» в її проекції на музичне начало видається в цьому ракурсі цілком доречною, оскільки дозволяє вловити глибинний рівень змісту, який, хоч і присвоює собі в значній мірі специфіку європейського художнього мислення, все ж у своєму первинному значенні завжди спирається на національне світовідчуття у його духовно-філософських вимірах, у його особливому способі поєднання музичної інтонації та слова.

Спочатку звернемось до категорії «концепту» і її основних характеристик, які в прямому чи опосередкованому значенні можуть проектуватись на музичний зміст загалом і на програмну інструментальну музику зокрема.

У новішому філософському словнику розглядається «концепт (від лат. Conceptus - акт зібрання, сприйняття, зачаття)», як «схоплювання» смислів (проблеми) в єдності мовленнєвого висловлювання.

Термін «концепт» введений у філософію середньовічним вченим Абеляром в зв'язку з аналізом проблеми універсалій, що вимагала розділу мови і мовлення [6, с. 1080]. Висловлена промова, за Абеляром сприймається як «концепт в душі слухача»[1, с. 121].

Абеляр вважав, що концепт не є процесом інтелектуального (intellectus) осмислення предметів і процесів, а є результатом активної діяльності піднесеного духу, здатного до креативного наповнення і укладення (concipere) смислів. Тобто, ще за середньовічною філософією Абеляра, концепт не тотожний поняттю чи категорії, а вищий і складніший за них.

Цитована стаття 3 «Нової філософської енциклопедії наголошує духовно-особистісну природу концепту у порівнянні з раціональнооб'єктивною сутністю поняття. В ній наголошується: «Концепт формується мовленням, яке розгортається в духовній площині з ії 
ритмами, енергією, жестикуляцією, інтонацією, безкінечними уточненнями, що складають смисл коментаторства.

Концепт гранично суб’єктний. Змінюючи душу індивида, що обдумує сутність явища, він при своєму формуванні передбачає іншого суб'єкта (слухача, читача), актуалізуючи смисли у відповідях на його запитання. Зверненість до слухача завжди передбачала одночасну зверненість до трансцендентного джерела мовлення - до Бога. Пам'ять і уява - невід'ємні властивості концепту, спрямованого, 3 одного боку, на розуміння тут і тепер, з іншого боку - концепт синтезує в собі три здібності душі і як акт пам'яті орієнтований на минуле, як акт уяви - в майбутнє, як акт судження - в теперішнє» [6, с. 1080].

Наведемо ще кілька міркувань видатних мислителів минулого, які безпосередньо виводять категорію «концепту» на спосіб пізнання і співпереживання дійсності в мистецтві. Зокрема Хома Аквінський визначає концепт як природне внутрішнє осягнення зовнішнього об'єкту (речі) подумки, і вираз цього осягнення через якийсь окреслений знак, символ, в певних ситуаціях - через їх сукупність і взаємодію, але в будь-якому випадку через єдність ідеального і матеріально-феноменального [6]. Як видається, важко знайти точнішу характеристику утворення музичних образів спочатку в уяві композитора, а потім його співпереживання слухачем.

На мистецько-творчу домінанту концепту звертали увагу й мислителі Нового часу, зокрема такі видатні філософи німецької класичної школи як Імануїл Кант та Фрідріх Шелінг, визначаючи сутність «схоплення змісту» через розмаїті фігури творчості [6, с. 1080].

Серед сучасних українських філософів з терміном «концепт» дуже послідовно працює Анатолій Свідзинський, вміщуючи його передусім в царині національної культури, тому видається суттєвим дещо докладніше опертись на його бачення сутності і ролі концепту у певному національному суспільстві - оскільки саме на цьому ставить дослідник основний акцент, а ще тому, що саме такий підхід найбільше відповідає науковій меті поданої статті - розкрити специфіку концепту у його компаративних зіставленнях «Европа - Китай». В зв'язку із прив'язкою концепту до своєрідної національної традиції різних народів дослідник вводить надзвичайно важливе поняття «міфологічної концептосфери», зазначаючи, що вона має не лише культурно-духовний сенс, але й цілком практичне онтологічне підгрунтя для певного соціуму: «Сукупність міфів певного колективу, супутні їм уявлення, які можуть бути не оформлені сюжетно (прикмети, вірування, табу та 
інші форми народної культури) творять міфологічну концептосферу, яка забезпечує стабільність соціяльного буття та належну орієнтацію членів колективу в різних життєвих ситуаціях» [10, с. 75].

Разом з тим той же автор не відкидає наявності спільних для всіх подає перелік універсальних концептів, котрі однак по-різному переосмислюються на кожному цивілізаційному витку історії та в кожній національній культурі: «Концепти виступають не лише як найважливіші витвори культури, мови, а й як двигуни культури, засіб ефективного впливу на індивіда та формування його як повноцінного члена соціюму. Це стає можливим тому, що концепти віддзеркалюють не просто дуже загальні поняття, вони містять в собі оцінку дійсности, викликають певні емоції, впливають на формування цінностей. Прикладами концептів є «Бог», «природа», «світ», «час», «суспільство», «народ», «культура», «цивілізація», «свобода», «закон», «право», «держава», «мораль», «людина», «любов», «слово», «творчість» і т. д. [10, с. 179].

В зв'язку із вищевикладеним, а особливо з впровадженням визначення «міфологічної концептосфери» ${ }^{1}$ вартує кілька зауваг зробити щодо ключового - як для концепту, так і для теми поданої статті, тобто можливості застосування терміну «концепт» для інструментальної програмності - поняття «національного світовідчуття», що природним чином кореспондує і узгоджується з поняттям «національної ментальності». Здебільшого в це поняття вкладається узагальнення своєрідних засад мислення, переживань, естетичних пріоритетів і самого суспільно-економічного укладу, що в кожній нації складаються залежно від іï ментального комплексу. «Загальні категорії уявлень», «уява», «бачення світу», «глибинні і архаїчні пласти психіки», «неусвідомлене», «повсякденна сторона свідомості», «установки», «поведінка» - все це визначення ментальності [4, с. 193-194]. Вони так чи інакше заторкують більш звичні для загалу визначення «національного характеру». Один із засновників школи «Аналів», Олександр Гуревич, взагалі вважає, що «певна розмитість поняття обумовлена самою природою феномену: ментальність всюдисуща, вона пронизує все людське життя, присутня на всіх рівнях свідомості і поведінки людей, а тому так важко ії̈ визначити, ввести в якісь рамки» [4, с. 195]. Проте існує ряд уточнюючих категорій, що спрямовують небажану розмитість ментального у окреслене русло, серед них - і поняття концепту,

${ }^{1}$ В деяких дослідженнях зустрічаються й інші означення «концептосфери»: морально-етична, фольклорна, екзистенційна, мистецька та ін., проте за змістом вони кореспондують із поданою дефініцією. 
яке вельми переконливо пов'язує із ментальним світом Ю. Степанов: «концепт - це немов би згусток культури у свідомості людини; те, у вигляді чого культура входить у ментальний світ людини. I, з іншого боку, концепт - це те, за допомогою чого людина - проста, звичайна людина, не «творець культурних цінностей» - сама входить у культуру, а в деяких випадках і впливає на неї» [11, с. 42-43].

Подані міркування викликають одразу два закономірні запитання. Перше: в чому полягає специфіка китайських національно-традиційних концептів (за Свідзинським - елементів міфологічної концептосфери), тобто ії відмінність від європейських версій універсальних концептів? Друге, ширше, що містить кілька підпитань: наскілька музика сама собою може трактуватись як «концепт» у вищезгаданому філософсько-естетичному смислі, i/або які власні внутрішні концепти вона в собі містить, та наскільки їх можна окреслити в тому чи іншому національному континуумі, виходячи із трактування у ньому музики та їі суспільної і/або індивідуальної ролі?

Щодо першого питання, то відповідь на нього доволі очевидна і міститься в багатьох як давніх філософських вченнях, так і в сучасних наукових дослідженнях. Наведемо одне із узагальнюючих компаративних визначень особливостей китайського світосприймання у порівнянні з європейським: «основна специфіка традиційно-китайської системи філософського мислення у всіх їі модифікаціях (від легізму та конфуціанства до даосизму та китайського буддизму) полягає в тому, що у центрі уваги знаходиться не індивідуально-особистісне сприйняття й усвідомлення проблеми буття і місця в ньому самої людини, а соціально значуща і детермінована зовнішніми силами (небо, дао) поведінка людей, тобто соціальна етика і політика, які у суспільстві мають першочергове та виключне значення» [2, с. 125].

В цьому контексті привертає виключну увагу концепт Дао, що належить до одного із ключових у китайській міфологічній концептосфері: «давньокитайське слово дао має широкий спектр значень: дорога, шлях, спосіб, засіб, метод, мистецтво, закон, принцип, істина, вчення, погляд, говорити, виражати, приносити жертву духу дороги. I більшість із цих значень маються на увазі та обігруються у філософських пам'ятках, творах літератури та фразеологічному фонді китайської мови» [8, с. 127].

У поданому переліку значень Дао можемо помітити виразні паралелі до вказаних Свідзинським універсальних концептів, зокрема «істини», «творчості» (в Дао: мистецтво), «права» (в Дао: закону). 
Проте є ще одне тлумачення Дао, яке кардинально відрізняється від усіх концептів європейської духовнох традиції - це його тлумачення як порожнечі, тобто як субстанції, яка містить в собі все суще і ніколи не залишається незмінною, тому не може бути осягнута i сконкретизована, «бо все, що було і буде про нього сказане, - це характеристики не Дао, а чогось іншого (із чжану 1 «Даодецзіну»: 道可 道, 非常道。Дао, яке можна о-мовити, не є постійним Дао). Тому, як би не намагалися мислителі всіх народів означити, пояснити сутність Дао, такі спроби приречені на поразку» [12].

I в цьому тлумаченні Дао як непізнаваного і неможливого до конкретної дефініції знову варто навести порівняння з європейським розумінням буття - небуття: «Якщо на Заході «ніщо не виникає з нічого», то на Сході «все виникає з нічого», тому «проблема Небуття в далекосхідній філософії в концептуальній сутнісно-практичній формі перетворюється в особливо необхідний зміст для життя людини» [3].

Отже, як історично сформоване, так і сучасне трактування «концепту» дозволяє збагнути як його універсалії, актуальні для всіх типів людської цивілізації, так і специфіку застосування в окремих національно-культурних ареалах.

Національна питома інтонація, тим більше органічно синтезована зі словом, яке вона виражає, по-різному буде розшифровуватись європейцем і представником китайської культурної традиції. Це дуже важлива передумова правильного розуміння змісту музичних творів різних жанрів, написаних в позаєвропейському культурному континуумі, причому це розуміння торкається як образно-смислового навантаження їх взаємодії зі словом, ритуалом, символікою тембрального звучання та інших елементів цілісного художнього образу, так і самого інтонаційного комплексу, що лежить в основі музичного твору.

Таке припущення щодо різного «чуття» тих самих елементів музичного твору опосередковано підтверджується аналогією з мовнолітературною сферою. На відмінність мовно-смислових концептів, виражених в різних мовах тим самим словом, вказує вище цитований автор А. Свідзинський, наголошуючи, що «національно та культурно специфічними можуть виявлятися концепти, представлені навіть у близькоспоріднених мовах, таких як українська та російська. Так, український концепт «рушник» не адекватний російському «полотенце» і містить у порівняння з російським значно більше культурно маркованих змістів, що закріплені у так званих прецедентних текстах (фольклорних та літературних творах, широко знаних носіями куль- 
тури). Тому і українське слово рушник далеко не у всіх контекстах може бути заступлене російським словом полотенце... Навіть основні репрезентанти (фундаментальних, одних із найважливіших в свідомості кожної людини - Лу Цзе) концептів - слова мати і мать - виявляються за змістом не цілком еквівалентними!» [10, с. 168].

Для нас в цих визначеннях є надзвичайно важливим, оскільки різнорівневі, різновекторні імпульси, що відображаються в ментальній структурі, що у вищенаведеній цитаті проектуються на мовно-смислові ряди споріднених мов, безперечно, чи не найповніше концентруються в національних мистецьких традиціях, в тому числі в цілковито специфічний спосіб - в національній музиці. Внаслідок вищенаведених міркувань приймаємо гіпотезу про наявність специфічних китайських культурних концептів (на двох рівнях: як національну версію універсальних концептів та як наявність самоцінних концептів, що принципово відрізняються від європейських версій) як таку, що може бути застосована в дослідженні китайської фортепіанної програмної музики.

Тому природно переходимо до відповіді на друге питання: наскільки коректно застосовувати окреслення «концепту» до музики? Тут теж можемо опертись на ряд авторитетних джерел, зокрема на праці одеської дослідниці Олександри Самойленко, а передусім на їі фундаментальну монографію «Музикознавство і методологія гуманітарного знання. Проблема діалогу» [9]. Проаналізовані та узагальнені нею «типізуючі семантичні властивості музичного тексту» властиво і $\epsilon$ передумовами виведення концептів у музичній «ноосфері».

Ще стисліше торкається цієї проблематики праця Валерії Марік [5], присвячена, поміж іншими завданнями, розкриттю змісту феноменів «музичний концепт» і «музична концептосфера». Вона дає своє визначення концепту, яке дуже логічно підводить до прийняття музики як своєрідного «концепту першого рівня», або всезагального універсального (можна тут вжити також окреслення трансцендентальний) концепту, в який може інтегруватись ряд інших смислових концептів, безпосередніше пов'язаних з онтологічними рядами і в цій іпостасі точніше відображати духовні сутності різних національних культур. За В. Марік, «Концепт є образом, що став текстом. Текст, у свою чергу, виступає як єдність семантичних інтерпретацій концепту» [5, с. 8]. Вона теж вказує на багатовимірність концептів, які можуть набувати різного семантичного забарвлення і виступати у різній функції у творчому й духовно-координуючому процесі не 
лише у загальному філософському полі (як це було показано вище на прикладі філософсько-етичних концептів європейського походження - і Дао), але й в музиці.

«Музичний концепт - це внесення певного предметного сенсу в звукову структуру; при цьому дана структура проявляє свої можливості як невербальна мова. Необхідною властивістю музичного концепту стає актуалізація моменту сьогодення шляхом переживання; втім, таким чином музичний концепт виявляє важливість включеності, вбудованості в теперішній час для будь-якої концептуалізації. Слід підкреслити і особливу роль жанрово-стилістичного контексту у формуванні музичного концепту. Музична концептосфера, з одного боку, - система, що сполучає в єдине ціле концептуальні властивості музики в певних історико-стильових межах.., з іншого боку - індивідуальна композиторська поетика» [5, с. 12-13].

Відштовхуючись від поданого визначення музичного концепту і концептосфери, звернемо увагу на те, що авторка, безперечно орієнтуючись на європейську культурну домінанту, природнім чином виділила у його фундаментальний елемент «індивідуальну композиторську поетику». В китайському варіанті концепту на це місце варто би поставити суспільно-виховну роль, яка в китайській музичній творчості має тісний зв'язок з ритуально-церемоніальною традицією.

На це звернув увагу ще давній китайський філософ Конфуцій, що вважав: впорядкованість, узгодженість в музиці народу найбільш дієвим засобом для підтримання порядку в суспільстві і для оптимального духовного та інтелектуального виховання людини. Щоби визначити стан держави і рівень іiї розвитку, Конфуцій слухав китайську церемоніальну музику. Через неї він осягав гармонію світостворення сам, музичне виховання вважав найважливішим державним завданням [7, с. 56-59].

В зв'язку з цим можна висунути гіпотезу: орієнтири художнього змісту, що виникли на основі адаптації суто європейських елементів музичної культури в найширшому спектрі понять, які інтегрувалися в китайське музичне життя приблизно лише сто років тому, в китайській національній музиці неодмінно відображатимуть питомо ментальні знаки - і відображатимуть питомі концепти, які далеко не повністю перетинаються з європейськими, навіть за позірної схожості вербальних чи інших концептів, поставлених в якості ключових у центр того чи іншого звукового артефакту. 
Прикладом наведеної гіпотези може служити така самоочевидна «точка перетину» двох віддалених культурних традицій як програмність інструментальної музики. Загальним психологічним підгрунтям сприйняття програмної музики в різних цивілізаціях є природне прагнення знайти для музичної інтонації, фактурного розташування, ритмічних комплексів та інших засобів музичної виразності адекватний предметно-понятійний ряд, можливість накреслити сферу специфічних переживань, відчуттів, асоціацій, співставити музичні образи з вербальними (рідше візуальними, котрі врешті теж переводяться у вербальну площину) поняттями і образами.

Тут дуже важливо вникнути в природу програмного мислення чи, точніше, відбору програмної тематики у європейській музиці та творчості китайських композиторів. Одна з ключових відмінностей - тривалість часу застосування принципів програмності в творчості митців різних континентів. Якщо в Європі практика надання програмної назви інструментальним творами налічує кілька тисяч років - адже з'явившись ще в добу античності, вона лише в період Середньовіччя відступає на другий план, але потім поступово повертається у добу Ренесансу, а особливо бароко, як феномен передусім звукозображальний, звуконаслідувальний, програмність протягом значного періоду розвитку європейської музики активно еволюціонувала, здобуваючи все вагоміший вплив в процесах оновлення, розширення семантичного поля музики, ії̈ виразових засобів. У найрізноманітніших стилях, напрямках, національних школах програмність є суттєвим, невід'ємним компонентом художнього образу, що виявляє кожний раз свої нові якості. Тобто концепт програмності тут формується згідно зауваженій В. Марік закономірності «...виявити важливість включеності, вбудованості в теперішній час для будь-якої концептуалізації».

Не те в китайській культурі. Китайська музика, для європейських інструментів (головно для фортепіано та скрипки) на відміну від європейської розвивається не так давно, ії початки дослідники відносять до 20-х років XX ст., при тому від початку провідні композитори, що звертались до цієї сфери творчості, Лі Інхай, Ван Лісан, Цзян Веньє та інші, не просто переймали високорозвинуту європейську традицію інструментального мистецтва, а трансформували і збагачували ії оригінальними здобутками китайської культури, наповнювали символікою і асоціативними рядами національного духовного континууму, а головне - зовсім в іншому ключі трактували 
головний концепт, закодований у програмності. Тому звертаємо увагу ще на одну відмінність програмності у музиці китайських композиторів - вона репрезентує китайську культурну традицію в синтезі з європейськими надбаннями музично-виразової системи для суто європейських інструментів. Концептом національної культури в цих опусах переважно виступають програми, що в той чи інший спосіб розкривають філософсько-етичні засади конфуціанства чи перевтілюють різні аспекти Дао.

На основі поданих міркувань приходимо до висновку, що термін «концепт» видається найбільш точним для розкриття способу мислення музикантів, чия ментальність і традиції виховання, формування світогляду і мистецькі цінності позначені вельми своєрідним ставленням до природи, універсуму і людини в колі буття, загалом відмінним від європейських трансцендентальних вимірів. Адже для китайців пізнання людини через поклоніння і обожествлення природи проходить крізь всю багато тисячолітню історію розвитку народу, його духовності і філософії, об’єднує даосизм, конфуціанство і буддизм, виступає одним із ментальних первенів світовідчуття. Підсумовуючи, можна метафорично зазначити, що якщо в європейській цивілізації поступово утверджується антропоцентризм як головний світоглядний постулат і трансцендентальний концепт, то східний образ світу в центр ставить природу, в єдності і повному розумінні $з$ якою повинна перебувати людина - згідно з засадами Дао. Музичне мистецтво обох цивілізаційних сфер виразно підтверджує і своєрідно трансформує ці фундаментальні концептуальні сутності, надаючи їм сучасних обертонів змісту і нових матеріальних форм виразу.

\section{СПИСОК ЛІТЕРТУРИ}

1. Абеляр П. Диалектика // П. Абеляр. Теологические трактаты. - М. : Прогресс, 1995. - $413 \mathrm{c}$.

2. Абрамова Н. А. Традиционная культура Китая и межкультурное взаимодействие : (Социально- философский аспект) / Н. А. Абрамова. - Чита : ЧитГТУ, 1998. - 258 с.

3. Аташ Б. М. Древневосточный концепт «пустоты» и его проявление в антропологической парадигме [Електроний ресурс]. - Режим доступу в Інтернеті: http://www.jurnal.org/articles/2010/filos4.html (24.04.2015)

4. Гуревич Исторический синтез и школа «Анналов» / А. Я. Гуревич. М. : Индрик, 1993. - 328 с.

5. Марік В. Б. Явища концепта і концептосфери в музичному мистецтві: до проблеми вічного образу : автореф. дис. ... канд. мист. за спеціальністю 
17.00.03 - Музичне мистецтво / Валерія Борисівна Марік. - Одеса, 2008. $17 \mathrm{c}$.

6. Неретина С. С. Новая философская энциклопедия : в 4 т. / С. С. Неретина ; [под редакцией В. С. Стёпина]. - М. : Мысль. 2001. - Т. 2. : Е - М. $634 \mathrm{c}$.

7. Переломов. Л. С. Конфуций: «Лунь юй». - М. : Восточная литература: PAH, 1998. $-168 \mathrm{c}$.

8. Пойнар Л. М. Семантичний простір фразеології як джерело інтерпретації концепту ІСТИННИЙ ШЛЯХ у картині світу китайського етносу / Л. М. Пойнар // Studia Linguistica. - K. : Київський національний університет імені Тараса Шевченка, 2012. - Вип. 6/2012 - С. 125-131.

9. Самойленко А. И. Музыковедение и методология гуманитарного знания. Проблема диалога : [монография] / А. И. Самойленко ; [ред. Н. Г. Александрова]. - Одесса : Астропринт, 2002. - 244 с.

10. Свідзинський А. В. Синергетична концепція культури / А. В. Свідзинський. - Луцьк : ВАТ «Волинська обласна друкарня», 2009. - 696 с.

11. Степанов Ю. Концепт / Ю. Степанов // Константы: Словарь русской культуры. Опыт исследования. - М. : Школа «Языки русской культуры», 1997. - C. $42-43$.

12. Шекера Я. В. Концепт порожнечі в китайській культурі: походження та репрезентація в поезії доби Сун (X-XIII ст.) [Електроний ресурс]. - Peжим доступу в Інтернеті: http://www.sinologist.com.ua (24.04.2015)

Лу Цзе. Категория «концепта» в парадигме европейской и китайской музыкальной культуры. В статье сопоставляются ведущие концепты европейской и китайской традиции, проецирующиеся на художественно-эстетическое мировоззрение китайских музыкантов и композиторов. Категория «концепта» в ее проекции на музыкальное начало представляется в этом ракурсе целесообразной, поскольку помогает охватить глубинный уровень содержания. Хотя китайские музыкальные концепты адаптируют специфику европейского художественного мышления, но в своем первичном значении всегда опираются на национальное мироощущение в его духовно-философских измерениях, в его особенном способе взаимодействия музыкальной интонации и слова.

Ключевые слова: концепт, концептосфера, национальная музыкальная культура, доминанта концепта.

Lew Tseu. A category of "concept « in the paradigm of the European and Chinese musical culture. Leading concepts of European and Chinese tradition, mapped to the artistically-aesthetic world view of the Chinese musicians and composers, is compared in the article. The category of «concept» in her projection on the musical essence appears in this foreshortening expedient, as helps to understand the deep level of maintenance. Although Chinese musical concepts adapt the specific of the European artistic thinking, but in the primary meaning always lean against national 
attitude in his spiritually-philosophical measuring, in his special method of co-operation of musical intonation and word.

Keywords: concept, national musical culture, the dominant concept.

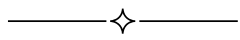

УДК 78.01+782.1/781.62

\section{У Хуймінь}

\section{ВОКАЛЬНЕ ІНТОНУВАННЯ ЯК ЧИННИК СЕМАНТИЧНОЇ ТИПОЛОГІї ОПЕРНОЇ ТВОРЧОСТІ}

У статті пропонується семантичний підхід до вокально-інтонаційного змісту опери, водночас доводиться актуальність типологічної характеристики жанрової форми опери з боку семантичних властивостей вокального інтонування. Виявляються основні рівні семантичної типології оперної творчості у їі естетичному та музично-інтерпретативному призначенні, характеризуються провідні способи оперного вокального інтонування (оперна вокальна поетика).

Ключові слова: оперне вокальне інтонування, оперна семантика, оперна вокальна поетика.

Вокальне інтонування є достатньо автономним виконавсько-інтерпретативним феноменом, що має власні технологічні показники та образні настанови. Але в контексті жанрової форми опери, тобто у системі оперних музично-виразових засобів воно набуває нових якостей, з одного боку, виявляючи залежність від інших компонентів оперного тексту, дієво-видовищного та словесно-поетичного, водночас набуваючи нової художньо-семантичної ваги, організаційної значущості. Тому воно виявляється здатним виступати в якості інструменту семантичної типології опери на іiї основних жанрово-композиційних рівнях.

Узагальнення положень досліджень [3; 9], пов'язаних з вивченням концептуальних сторін оперного твору, дозволяє дійти висновку, що перший рівень зумовлений визначенням найбільш загальної смислової скерованості оперного жанру, є мета-історичним та представляє характеристики оперної творчості за допомогою узагальнюючих визначень слів, драматичної дії, музичної експресії; дані поняття $є$ фундаментальними і наскрізними для всіх форм і видів опери. Даний рівень історично визначається в епоху бароко і класицизму; його го- 